\title{
Characterization and biological activity of relaxin in porcine milk
}

\author{
Amy-Lynn Frankshun, Teh-Yuan Ho, David C Reimer ${ }^{1}$, Joseph Chen, Salamia Lasano ${ }^{2}$, \\ Bernard G Steinetz ${ }^{2}$, Frank F Bartol ${ }^{3}$ and Carol A Bagnell
}

Department of Animal Sciences, Rutgers, The State University of New Jersey, 84 Lipman Drive, New Brunswick, New Jersey 08901, USA, ${ }^{1}$ Laboratory Animal Services, Rutgers, The State University of New Jersey, Piscataway, New Jersey 08854, USA, ${ }^{2}$ Nelson Institute of Environmental Medicine, New York University School of Medicine, Tuxedo, New York 10987, USA and ${ }^{3}$ Department of Anatomy, Physiology and Pharmacology, Cellular and Molecular Biosciences Program, Auburn University, Auburn, Alabama 36849, USA

Correspondence should be addressed to C A Bagnell; Email: bagnell@aesop.rutgers.edu

C A Bagnell and F F Bartol contributed equally to this work

\begin{abstract}
A lactocrine mechanism for delivery of maternally derived relaxin (RLX) into the neonatal circulation as a consequence of nursing was proposed for the pig. Immunoreactive RLX was detected in colostrum and in the serum of newborn pigs only if they were allowed to nurse. Milk-borne RLX concentrations are highest during early lactation $(9-19 \mathrm{ng} / \mathrm{ml})$, declining to $<2 \mathrm{ng} / \mathrm{ml}$ by postnatal day 14 . Whether milk-borne RLX is bioactive is unknown. Evidence that RLX concentrations in milk are higher than in maternal circulation in several species suggests the mammary gland as a site of local RLX production. It is unknown whether the porcine mammary gland is a source of RLX. Therefore, objectives were to evaluate RLX bioactivity in porcine milk during the first 2 weeks of lactation, identify the form of RLX in porcine milk, and determine whether mammary tissue from early lactation is a source of milk-borne RLX. Milk RLX bioactivity was determined using an in vitro bioassay in which cAMP production by human embryonic kidney (HEK293T) cells transfected with the human RLX receptor (RXFP1) was measured. RLX bioactivity was highest at lactation day (LD) 0 , decreasing to undetectable levels by LD 4. Immunoblot analysis of milk proteins revealed an $18 \mathrm{kDa}$ band, indicating proRLX as the primary form of RLX in porcine milk. ProRLX protein and transcripts were detected in porcine mammary tissue on LD 0 and 7 . Results support the lactocrine hypothesis by defining the nature and a potential source for bioactive proRLX in porcine colostrum/milk.

Reproduction (2011) 141 373-380
\end{abstract}

\section{Introduction}

Relaxin (RLX), a prototypical milk-borne peptide hormone (Bagnell et al. 2009), is found in the colostrum of several species including humans (Eddie et al. 1989), dogs (Goldsmith et al. 1994), rats (Steinetz et al. 2009), and pigs (Yan et al. 2006). Immunoreactive RLX is detectable in the systemic circulation of newborn pigs only if they are allowed to nurse (Yan et al. 2006). Detection of RLX in both colostrum and the neonatal circulation during the first few days of life correlates with the time of gut closure in pigs, estimated to occur at 24-48 h after birth (Lecce 1973). Similar studies in dogs showed that milk-borne RLX is transmitted from lactating bitches to their offspring via nursing and is absorbed into the systemic circulation (Goldsmith et al. 1994). The lactocrine hypothesis for maternal programing of neonatal tissues was proposed to explain how milkborne RLX, transmitted from mother to offspring as a specific consequence of nursing, is absorbed into the neonatal circulation and acts on RLX receptor (RXFP1)positive neonatal tissues to affect their development (Bartol et al. 2008, Bagnell et al. 2009).

RLX bioactivity has been measured using various techniques based on the actions of RLX in target tissues. Fevold et al. (1930) devised a guinea pig pubic symphysis palpation bioassay to assess mobility of the pubic symphysis subjectively after RLX-induced separation of the pubic bones. Later, a uterine contractility bioassay was developed based on RLX inhibition of myometrial contractions (Krantz et al. 1950). The mouse interpubic ligament bioassay was conceived as a simpler, direct measure of RLX bioactivity since estrogen-primed mice respond to RLX with a dosedependent lengthening of the interpubic ligament (Kroc et al. 1959). In 1990, an in vitro bioassay was developed based on RLX stimulation of CAMP production using primary cultures of human endometrial 
cells (Fei et al. 1990) and later refined using the human monocytic THP-1 cell line (Parsell et al. 1996). Most recently, human embryonic kidney (HEK293T) cells stably transfected with the human RXFP1 (HEK293TRXFP1) were used to measure cAMP response and RLX bioactivity (Hsu et al. 2002).

RLX, a member of the RLX family of peptides (Bathgate et al. 2006), is synthesized as single-chain, $23 \mathrm{kDa}$ preproRLX (Gast 1982, 1983, Haley et al. 1982) containing a signal peptide, connecting peptide and A and B chains. The signal peptide is cleaved and translocated across the endoplasmic reticulum (Gast 1982, 1983) to form $18 \mathrm{kDa}$ proRLX (Haley et al. 1982, Layden \& Tregear 1996). Further processing of the connecting peptide results in the native $6 \mathrm{kDa} \mathrm{RLX}$ molecule found in circulation (O'Byrne et al. 1989). The amino acid motif Arg-X-X-X-Arg-X-X-Ile, located in the middle of the $B$ chain, is required for RLX bioactivity (Bullesbach \& Schwabe 2000).

Sources of RLX are species-specific. Whereas RLX is synthesized primarily by corpora lutea in the pig (Sherwood \& O'Byrne 1974) and rat (Sherwood 1979), in other species, it is a product of the uterus (Pardo et al. 1980) and placenta (Eldridge \& Fields 1985, Stewart \& Papkoff 1986). There is also evidence for local RLX production in other tissues (Bryant-Greenwood et al. 1980, Sakbun et al. 1990). Evidence that RLX concentrations in milk are higher than in the maternal circulation (Sherwood et al. 1981, Eddie et al. 1989, Goldsmith et al. 1994) suggests that RLX is either produced locally by the mammary gland or synthesized elsewhere and concentrated in milk.

Support for the mammary gland as a source of RLX comes from immunolocalization studies in the guinea pig mammary gland (Peaker et al. 1989) and in human breast tissue (Mazoujian \& Bryant-Greenwood 1990). RLX transcripts were also detected in the rat mammary gland of late pregnancy and early lactation (Gunnersen et al. 1995), in normal and neoplastic human breast tissue (Tashima et al. 1994), and in neonatal pig adipose tissue (Hausman et al. 2006). Whether porcine mammary tissue is a site for RLX production is unknown. To confirm and extend previous studies (Frankshun et al. 2009), objectives here were to evaluate RLX bioactivity in porcine milk during the first 2 weeks of lactation using an in vitro bioassay, identify the form of RLX found in porcine colostrum $/ \mathrm{milk}$, and determine whether porcine mammary tissue could serve as a source of milk-borne RLX.

\section{Results}

\section{Validation of the cell-based RLX bioassay}

Validation of the cell-based RLX bioassay involved evaluation of cell system response to increasing amounts of porcine RLX standard added to milk extract that had low RLX concentrations (LD 14 milk). A dose-dependent

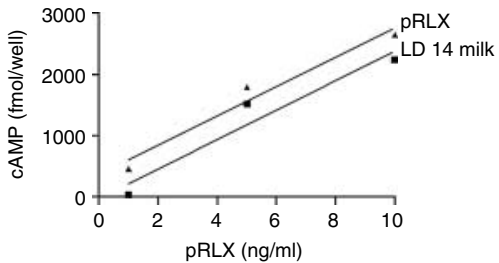

Figure 1 Determination of assay recovery for the transformed HEK293T cell-based RLX bioassay. Increasing amounts of porcine RLX were added to lactation day (LD) 14 porcine milk extract and compared to effects of a porcine RLX standard when added in increasing concentrations to the HEK293T cell bioassay. A test of heterogeneity of regression between the lines was not significant $(P>0.05)$, indicating similar effects of increasing milk extract on transformed HEK293T cell CAMP generation to those observed for the porcine RLX standard.

increase in cAMP production by transformed HEK293TRXFP1 cells was observed consistently in response to increasing concentrations of porcine RLX (Fig. 1). A test for heterogeneity of regression between lines representing porcine RLX in assay buffer and LD 14 milk was not significant. This indicated similar patterns of increase in cAMP production by transformed HEK293T-RXFP1 cells with the addition of RLX, providing no evidence against parallelism (Fig. 1). The area under each curve was calculated and revealed a quantitative recovery of $79.6 \%$. Defined as the minimal RLX concentration required to elicit a detectable cAMP response, sensitivity of the assay was determined to be $100 \mathrm{pg}$ RLX. Production of cAMP by HEK293T-RXFP1 cells was not affected when these transfected cells were incubated with either insulin or insulin-like growth factor 1 (IGF1; data not shown). Consistently, no effect on cAMP production was detected when non-transfected HEK293T cells were incubated with porcine RLX (Frankshun et al. 2009). Collectively, these data show assay specificity.

\section{Biological activity of $R L X$ in porcine milk during the first 2 weeks of lactation}

The cAMP response of the HEK293T-RXFP1 cell line was used to test the biological activity of milk-borne RLX as illustrated in Fig. 2. Milk from LD 0 produced an average of $3040 \pm 229 \mathrm{fmol} /$ well of cAMP, indicating the presence of bioactive RLX in these milk extracts. RLX bioactivity decreased $(P<0.05)$ after LD 0 and was undetectable by LD 4 . This bioactivity pattern was similar to that observed for immunoreactive RLX concentrations in the same milk extracts (Fig. 2, inset). Immunoreactive RLX concentrations in milk extracts were highest on LD 0 , with an average concentration of $15.4 \mathrm{ng} / \mathrm{ml}( \pm 2.2 \mathrm{ng} / \mathrm{ml})$. Milk RLX concentrations declined $(P<0.01)$ from LD 0 , averaging $<1 \mathrm{ng} / \mathrm{ml}$ on LD 14 (Fig. 2, inset). 


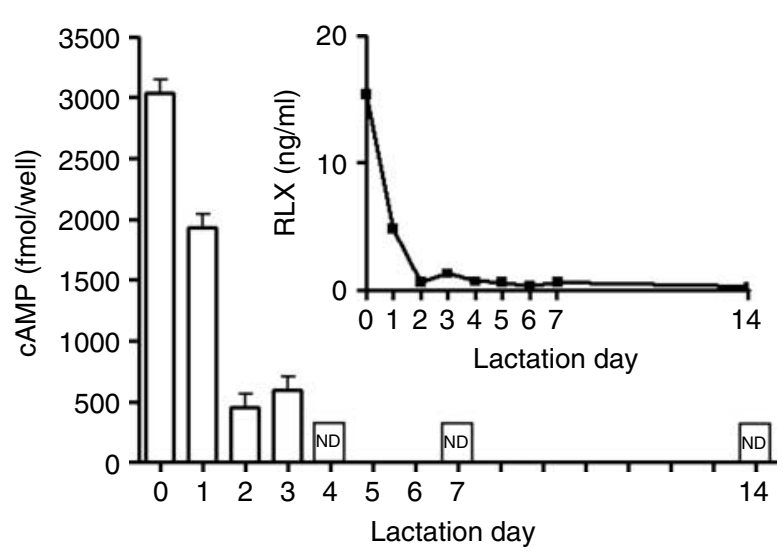

Figure 2 Relaxin bioactivity patterns in porcine milk extracts during the first 2 weeks of lactation relative to RLX concentrations determined by RIA (inset). Relaxin bioactivity decreased $(P<0.05)$ within the first few days of lactation and fell $(P<0.05)$ to nondetectable (ND) levels by day 4 of lactation. The bioactivity pattern was reflected by data for immunoreactive RLX concentrations in the same milk extract samples (inset). Data are expressed as LSM \pm s.E.M. $N=3$ sows/group.

\section{Prorelaxin in porcine milk}

An $18 \mathrm{kDa}$ band, corresponding in size to proRLX (Layden \& Tregear 1996), was identified in porcine milk obtained on LD $0-4,7$, and 14 , with no evidence of the $6 \mathrm{kDa}$ native RLX molecule (Fig. 3A). Bands indicative of both $18 \mathrm{kDa}$ proRLX and $6 \mathrm{kDa}$ native RLX molecules were observed for luteal tissue protein extract used as a positive control. Results for detection of immunoreactive RLX in milk extracts and luteal tissue were similar when using either the Gg or R6 anti-porcine RLX antisera; thus, only data generated using the Gg antiserum are shown (Fig. 3A). Neither form of RLX was detected in the milk replacer used as a negative control. Densitometric analysis indicated that relative levels of immunoreactive proRLX in porcine milk were highest on LD 0 , decreased curvilinearly thereafter through LD 4, following a cubic pattern $(Y=-957.49 x$ $\left.+335.96 x^{2}-39.60 x^{3}+1302.664 ; P<0.01 ; R^{2}=84 \%\right)$, and remained low through LD 14 (Fig. 3B).

\section{Prorelaxin protein and $m R N A$ expression in porcine mammary tissue}

Immunoblot analyses of porcine mammary tissues from LD 0 and 7 revealed an $18 \mathrm{kDa}$ band, corresponding in size to porcine proRLX, with no evidence of the $6 \mathrm{kDa}$ native RLX molecule (Fig. 4A). Relative levels of proRLX protein in porcine mammary tissue decreased from LD 0 to $7(P<0.05)$. Again, porcine luteal tissue protein extract contained both 18 and $6 \mathrm{kDa}$ molecules, corresponding to pro- and native RLX. Cervical tissue protein from postnatal day 0 , used as a negative control, showed no evidence of either 18 or $6 \mathrm{kDa}$ forms of
RLX. QPCR data indicating $R L X$ mRNA expression by porcine mammary tissue from LD 0 and 7 are shown in Fig. 4B. There was no difference in relative levels of $R L X$ mRNA expression between LD 0 and 7 .

\section{Discussion}

Immunoreactive RLX was first identified in human colostrum within 3 days of parturition and in breast milk up to 6 weeks post partum (Eddie et al. 1989). Since then, RLX has been detected in the colostrum/milk of several species (Goldsmith et al. 1994, Steinetz et al. 2009) including the pig (Yan et al. 2006). Evidence that RLX concentrations in milk are higher than in the maternal circulation during lactation (Sherwood et al. 1981, Eddie et al. 1989, Goldsmith et al. 1994) led to the suggestion that RLX is either produced locally by the mammary gland or synthesized elsewhere and concentrated in milk (Eddie et al. 1989). Recently, the lactocrine hypothesis for maternal programing of neonatal tissues was proposed to explain how RLX, a prototypical milkborne growth factor communicated from mother to offspring as a consequence of nursing, is absorbed into the neonatal circulation and acts on target tissues to affect their development (Yan et al. 2006, Bartol et al. 2008). This study was designed to determine whether RLX in porcine colostrum/milk is biologically active, identify the primary form of RLX present in porcine colostrum/milk, and establish whether the porcine

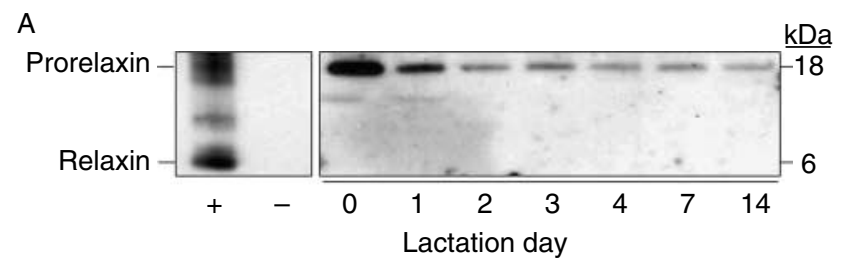

B

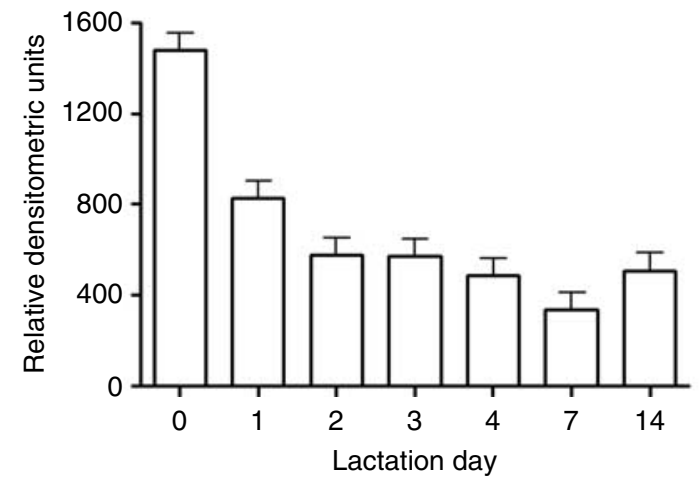

Figure $3 \mathrm{Imm}$ moreactive proRLX in sow milk extracts from lactation days $0-4,7$, and 14 . (A) Representative immunoblot indicating the presence of $18 \mathrm{kDa}$ proRLX. (+) Positive control, pregnant sow luteal tissue extract. (-) Negative control, milk replacer. (B) Relative expression of proRLX was quantified by densitometry and expressed as relative densitometric units. $L S M \pm$ s.E.M. $N=4$ animals per group. The decrease in relative abundance of proRLX between days 0 and 4 was best described by a cubic function $\left(Y=-957.49 x+335.96 x^{2}-\right.$ 39.60x $\left.x^{3}+1302.664 ; P<0.01 ; R^{2}=84 \%\right)$. 


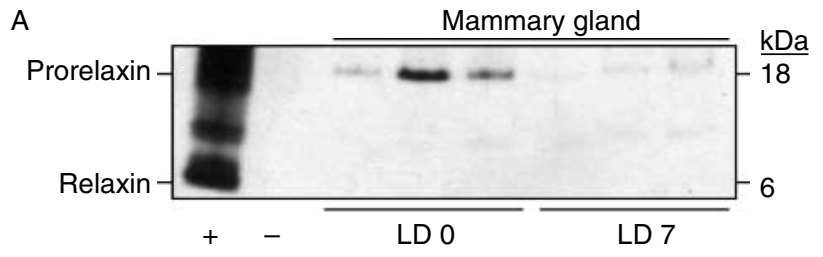

B

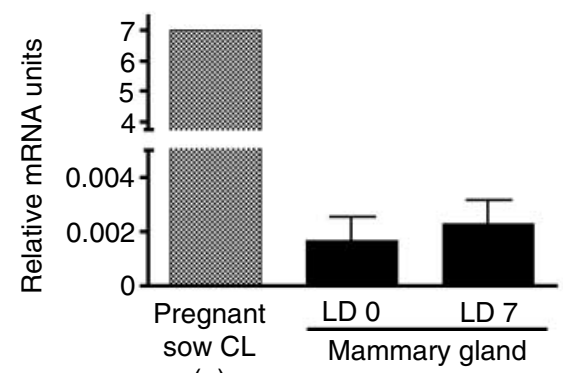

$(+)$

Figure 4 Prorelaxin protein and mRNA expression in sow mammary tissue from lactation days 0 and 7 . (A) Immunoblot analysis of immunoreactive proRLX (18 kDa) in sow mammary tissue. (+) Positive control, pregnant sow corpus luteum. (-) Negative control, PND 0 gilt cervix. (B) Sow mammary $R L X$ mRNA expression. Data are expressed as $L S M \pm$ s.E.M. $N=3$ sows/group.

mammary gland might serve as an endogenous source of lactocrine-active RLX.

When immunoreactive porcine RLX was detected in porcine milk, it was hypothesized that such RLX was biologically active (Yan et al. 2006, Frankshun et al. 2009). This was based on the fact that the antibody used in the porcine RLX RIA detected only intact RLX, with $A$ and $B$ chains linked by disulfide bonds, and did not detect isolated peptide chains or reduced-alkylated RLX (O'Byrne \& Steinetz 1976). Results presented here support that hypothesis by showing that RLX bioactivity was highest in milk from LD 0 and decreased within the first few days of lactation, dropping below bioassay sensitivity by LD 4 . This bioactivity pattern was similar to the pattern of immunoreactive RLX concentrations determined for the same milk samples (Fig. 2). The decline in both RLX bioactivity and RLX concentrations in milk during early lactation correlates with the time of gut closure, estimated to occur between 24 and $48 \mathrm{~h}$ after birth in pigs (Lecce 1973). RLX concentrations in whole porcine milk were $\sim 17 \mathrm{ng} / \mathrm{ml}$ on LD 0 and dropped to about $2 \mathrm{ng} / \mathrm{ml}$ by LD 14 (Yan et al. 2006). Results are similar to those reported for dogs, in which biologically active milk-borne RLX was detected at relatively high concentrations $(\sim 13-15 \mu \mathrm{g} / \mathrm{ml})$ on LD 0 , dropping to $<100 \mathrm{ng} / \mathrm{ml}$ by week 4 of lactation (Goldsmith et al. 1994, Steinetz et al. 2008). Similarly, in pregnant women at term, mean RLX concentrations in milk decreased between 3 days and 6 weeks of lactation (Eddie et al. 1989). Collectively, results are consistent with present findings indicating that biologically active proRLX is present in porcine milk and available for lactocrine transmission to neonatal pigs.
Results of this study show clearly that the $18 \mathrm{kDa}$ proRLX molecule is the primary form of RLX in porcine milk. No evidence was obtained indicating conversion of proRLX to the $6 \mathrm{kDa}$ native form of RLX. Given that proRLX in porcine milk induced cAMP production in the cell-based in vitro bioassay used here, results suggest that cleavage of the RLX-connecting peptide is not necessary for biological activity of porcine RLX. Results agree with data published for other species. Recombinant equine proRLX secreted by the MAC-T mammary epithelial cell line (Neumann et al. 2006) and recombinant marmoset proRLX (Zarreh-Hoshyari-Khah et al. 2001) produced by insect cells were both biologically active, with no evidence for conversion to the $6 \mathrm{kDa}$ form. Additionally, recombinant rat proRLX produced by COS cells (Soloff et al. 1992), recombinant porcine proRLX expressed by CHO cells (Vu et al. 1993), and recombinant human proRLX expressed by canine and human mammary cancer cells (Silvertown et al. 2003) were all biologically active and not processed to the native $6 \mathrm{kDa}$ RLX molecule. In this regard, RLX is similar to IGF1 in that the pro-form of IGF1 displays bioactivity, but differs from insulin since proinsulin has no biological activity (Peavy et al. 1984). Whether secretion of proRLX into milk is a means of encrypting the RLX protein to extend its half-life, as reported for other milk peptides (Meisel 2005), is unknown.

With respect to the molecular size of porcine RLX found in circulation, multiple forms of immunoreactive RLX were identified in serum obtained from pregnant sows, including an $18 \mathrm{kDa}$ putative pro-form (BryantGreenwood et al. 1980). However, subsequent studies (O'Byrne et al. 1989) suggested that plasma RLX found in pregnant pigs immediately prepartum is secreted by the corpus luteum in a biologically active $6 \mathrm{kDa}$ form, with no evidence of higher molecular weight precursors. O'Byrne et al. (1989) used the rabbit anti-porcine R6 antiserum to detect native RLX in serum obtained from pregnant sows on gestational days 112-114. The R6 antiserum detects both $6 \mathrm{kDa}$ native RLX, as indicated above, and high molecular weight RLX precursors of porcine luteal origin (MJ Gast, personal communication). Results presented here confirm this observation, showing that both high $(18 \mathrm{kDa})$ and low $(6 \mathrm{kDa})$ molecular weight forms of RLX were detectable in luteal tissue extracts by immunoblotting using the R6 antiserum. These observations support the idea that $18 \mathrm{kDa}$ proRLX is the primary form of RLX likely to be produced by porcine mammary tissue and present in porcine colostrum.

Whether mammary tissue is a source of RLX or is produced elsewhere and concentrated from the maternal circulation in the porcine mammary gland is unknown. Studies in the guinea pig, human, dog, and rat indicated the mammary gland as a source of RLX. RLX was immunolocalized in epithelial cells that form the mammary duct system in guinea pigs (Peaker et al. 
1989), and expression of both $\mathrm{H} 1$ and $\mathrm{H} 2$ human RLX genes was detected in normal and neoplastic breast tissue (Tashima et al. 1994) providing support for local synthesis of RLX by breast tissue. Also, milk obtained from dogs that were ovariohysterectomized at term contained as much RLX as did milk of intact dogs through 5 weeks of lactation. Thus, in dogs, the source of RLX in milk cannot be the ovaries or uterus and is likely to be the mammary gland (Goldsmith et al. 1994). Treatment of rats with a monoclonal anti-rat RLX prevented ovarian RLX from reaching the mammary glands via the circulation but did not affect milk RLX concentrations, suggesting that the RLX detected in rat milk is primarily a product of the mammary glands and is not derived from circulating ovarian RLX (Steinetz et al. 2009). Results presented here indicate that RLX gene and protein expression are low in the porcine mammary gland during early lactation. These results support previous reports of low levels of maternal plasma RLX $(0.4 \mathrm{ng} / \mathrm{ml})$ by $37 \mathrm{~h}$ post partum in pigs (Sherwood et al. 1981). It is possible that the proRLX protein detected at LD 0 and 7 by immunoblot represents residual protein retained in tissues from mammary secretions at the time of biopsy. Data for milk RLX concentrations in ovariohysterectomized sows have not been reported and would help in determining the source of milk-borne RLX in pigs.

The possibility that milk-borne RLX found in colostrum during early lactation is coming from the corpus luteum and not from the mammary gland cannot be ruled out. RLX gene expression was detected in the corpus luteum at LD 2 by both northern blot analysis and in situ hybridization (Bagnell et al. 1990). In addition, RLX protein was localized in luteal cells throughout the corpus luteum during the first 2 weeks of lactation (Bagnell et al. 1987). However, if the corpus luteum is the source of milk-borne RLX, delivered via maternal circulation to be concentrated in the mammary gland, the $18 \mathrm{kDa}$ proRLX molecule should be detectable in maternal circulation. This is not the case. Only the $6 \mathrm{kDa}$ form of RLX has been detected in maternal serum immediately prepartum (O'Byrne et al. 1989), and only the $18 \mathrm{kDa}$ proRLX is detectable in porcine milk. Together, these results suggest that proRLX detected in milk does not come from the maternal circulation, but is produced locally as proRLX by mammary tissue.

Results presented here support and extend previous reports of bioactive proRLX in porcine milk that is available for delivery from mother to offspring via nursing (Yan et al. 2006, Frankshun et al. 2009). Given that neonatal porcine milk intake is estimated at up to $30 \%$ of body weight per day (Coalson \& Lecce 1973) and that concentrations of RLX in porcine milk within $48 \mathrm{~h}$ of birth range from 5 to $15 \mathrm{ng} / \mathrm{ml}$, individual neonates consume microgram quantities of potentially lactocrineactive RLX within 2 days of birth (Yan et al. 2006, Bagnell et al. 2009). Since RLX has trophic effects on both uterine and cervical tissues at PND 2 (Yan et al. 2005, 2008) and RXFP1 is expressed by porcine uterine (Yan et al. 2006) and cervical tissues from birth (Yan et al. 2008), it is reasonable to hypothesize a role for lactocrine-active RLX in development of the neonatal female porcine reproductive tract. The stage is now set for additional studies designed to test the lactocrine hypothesis and to determine specific effects of lactocrine-active RLX on reproductive development in the neonatal gilt.

\section{Materials and Methods}

\section{Materials}

HEK293T cells were obtained from the American Type Culture Collection (ATCC no. SD-3515, Manassas, VA, USA). The HEK293T-RXFP1 cell line and anti-porcine RLX serum (Gg) were generous gifts from Dr Gillian Bryant-Greenwood (University of Hawaii, Honolulu, HI, USA). In addition, a second anti-porcine RLX serum, R6, was used for both RIA and immunoblotting. Purified porcine RLX was kindly donated by Dr David Sherwood (University of Illinois, Urbana, IL, USA). Advanced DMEM-F-12 was purchased from Gibco. Fetal bovine serum (FBS) was obtained from Atlanta Biologicals (Lawrenceville, GA, USA). Antibiotics were purchased from Invitrogen. TRI Reagent and 3-isobutyl-1-methylxanthine were obtained from Sigma-Aldrich. The Amersham cAMP Biotrak Enzyme Immunoassay System was purchased from GE Healthcare (Piscataway, NJ, USA). Xylazine, telazol, yohimbine, and lidocaine were purchased from Henry Schein (Melville, NY, USA). RNeasy Mini kits and RNase-Free DNase Sets were obtained from Qiagen, Inc. Superscript III First-Strand Synthesis System for RT-PCR was obtained from Invitrogen. SYBR Green PCR Master Mix was purchased from Applied Biosystems (Foster City, CA, USA). Primers were synthesized by Sigma-Aldrich. Detergent-compatible protein assay kits (DC Protein Assay) were obtained from Bio-Rad Laboratories. HRP-conjugated anti-rabbit secondary antibody was purchased from Zymed (Carlsbad, CA, USA). Tricine gels $(10-20 \%)$ were obtained from Invitrogen. Nitrocellulose membranes were obtained from Bio-Rad Laboratories. The Renaissance Western Blot Chemiluminescence Reagent Plus kits were acquired from Perkin Elmer Life Sciences (Waltham, MA, USA). XOmatic films were purchased from American Imaging (South Plainfield, NJ, USA).

\section{Porcine milk collection, extraction, and mammary gland biopsy}

Milk was collected as previously described (Frankshun et al. 2009). Briefly, milk from purebred Yorkshire sows ( $N=4$ sows/ time point) was collected manually at the time of parturition (lactation day (LD) 0), daily through LD 7, and on LD 14. In addition, a commercial milk replacer for pigs (Advance LiquiWean; Milk Specialties, Carpentersville, IL, USA) was tested. Individual milk and milk replacer samples were diluted $1: 1$ with $200 \mathrm{mM}$ EDTA ( $\mathrm{pH}$ 7.0) to solubilize caseins and centrifuged (15 min at $4000 \mathrm{~g}$ at $4{ }^{\circ} \mathrm{C}$ ) to remove fat (Van Cott et al. 1996). 
The supernatant, herein referred to as milk extract, was stored at $-20{ }^{\circ} \mathrm{C}$ until subjected to further testing.

Mammary gland biopsies were collected from the same three lactating sows on LD 0 and LD 7. Sows were anesthetized with a combination of xylazine $(2.2 \mathrm{mg} / \mathrm{kg}$ body weight (BW)) and telazol (5.0 mg/kg BW) delivered i.m. (Ko et al. 1993). The site of biopsy collection was prepared with surgical scrub (betadine and ethanol), and a local anesthetic ( $2 \%$ lidocaine) was applied in a ring around the site of biopsy. A one inch keyhole incision was made to expose mammary gland tissue, and a punch biopsy was used to collect the mammary tissue followed by suturing the transected area in order to control milk loss and facilitate healing. The biopsy wound site was closed intradermally using 3-0 absorbable suture. A portion of the biopsied mammary tissue was fixed in $4 \%$ paraformaldehyde for histology, and the remainder was frozen in RNA Later (Qiagen) for molecular analysis. Yohimbine $(0.1 \mathrm{mg} / \mathrm{kg}$ BW i.m.) was administered to stimulate recovery from surgery. All procedures involving animals were reviewed and approved by the Rutgers University Animal Care and Facilities Committee (Protocol \#88-079), and were performed in accordance with the Guide for the Care and Use of Agricultural Animals in Research and Teaching (2010; Federation of Animal Science Societies, Champaign, IL, USA).

\section{$R L X$ in vitro bioassay and validation}

HEK293T-RXFP1 cells were grown in DMEM-F-12 containing $10 \%$ FBS, $1 \%$ penicillin-streptomycin-glutamine, and $1 \mathrm{mg} / \mathrm{ml}$ geneticin. Cells $\left(2 \times 10^{5}\right.$ cells/well) were cultured overnight in a 96-well culture plate and then pretreated with $0.25 \mathrm{mM}$ 3-isobutyl-1-methylxanthine for $20 \mathrm{~min}$ at $37^{\circ} \mathrm{C}$ (Kern et al. 2007). After incubation (30 min at $37^{\circ} \mathrm{C}$ ) with milk extracts from LD 0-7 and $14(20 \mu \mathrm{l})$, cells were lysed and total cellular cAMP was determined using the Amersham cAMP Biotrak enzyme immunoassay system. cAMP standards were run in duplicate, and unknown samples were run in triplicate. Interand intra-assay coefficients of variation (CV) were $6.3 \pm 1.0$ and $5.3 \pm 1.5 \%$ respectively. Dose dependence, sensitivity, and specificity of the RLX bioassay were reported previously (Frankshun et al. 2009). Assay recovery was determined by the addition of known amounts of porcine RLX standard (1, 5, and $10 \mathrm{ng} / \mathrm{ml}$ ) to LD 14 milk extracts and compared to a porcine RLX standard curve. All assay results were corrected for assay dilution effects.

\section{RLX RIA}

Immunoreactive RLX in milk extracts from LD 0-7 and LD 14 was measured using a homologous porcine RLX RIA validated for use with milk (Yan et al. 2006). Purified porcine RLX was used as the standard, and ${ }^{125}$ I-labeled tyrosyl porcine RLX was used as the radioligand. Antiserum R6 was used at a dilution of 1:20 000, and all standards and unknown samples were run in triplicate at a final volume of $500 \mu \mathrm{l}$ of PBS (pH 7.0) containing $1 \%$ BSA before the addition of antiserum and the radioligand. Inter- and intra-assay $\mathrm{CV}$ were $4.7 \pm 0.8$ and $1.0 \pm 0.3 \%$ respectively.

\section{Western blot analysis}

Proteins (20-30 $\mu \mathrm{g})$ in milk extracts, milk replacer extract, sow mammary tissue, and pregnant sow corpus luteum (500 ng), used as a positive control for RLX protein, were resolved on non-reducing 10-20\% Tricine gels under denaturing conditions by SDS-PAGE followed by transfer onto nitrocellulose membranes $(0.2 \mu \mathrm{m}$ pore size) via electroblotting. Membranes were blocked with $10 \%$ nonfat milk powder (NFMP) in Trisbuffered saline containing Tween 20 (TBST; $25 \mathrm{mM}$ Tris, $\mathrm{pH}$ 7.5, $0.14 \mathrm{mM} \mathrm{NaCl}, 3 \mathrm{mM} \mathrm{KCl}, 0.05 \%$ Tween 20) for $1 \mathrm{~h}$ at room temperature and then incubated with rabbit anti-porcine RLX serum (Gg or R6; 1:5000) in TBST-1\% NFMP overnight at $4{ }^{\circ} \mathrm{C}$. Membranes were washed with TBST and incubated with goat anti-rabbit IgG-HRP conjugate (1:10 000 in TBST-5\% NFMP) for $30 \mathrm{~min}$ at room temperature. After washing in TBST, membrane-bound antibodies were detected by ECL according to the manufacturer recommendations. Protein loading was monitored using actin as a reference. Chemiluminescence signals were quantified densitometrically from film using Scion Image for Windows (Scion Corporation, Frederick, MD, USA).

\section{RNA isolation, CDNA generation, and real-time RT-PCR}

Total RNA was isolated as previously described (Chen et al. 2010). Briefly, total RNA was isolated from mammary tissue (50 mg) using TRI Reagent and the RNeasy Mini kit. RT was performed with $500 \mathrm{ng}$ total RNA per sample using the PTC200 Peltier Thermal Cycler (Bio-Rad Laboratories, Inc.) and SuperScript III First-Strand Synthesis System for RT-PCR. All procedures were carried out following the manufacturer's instructions.

Real-time RT-PCR (quantitative PCR, qPCR) was performed using an Applied Biosystems Gene Amp 7000 Sequence Detection System (Applied Biosystems) with the SYBR Green method following the universal thermal cycling parameters indicated by the manufacturer as previously described (Chen et al. 2010). Primers for gPCR were designed using Primer Express Software (Applied Biosystems). For porcine RLX, the forward primer sequence was 5'-GCATGCGGCCGAGAATT- $3^{\prime}$, and the reverse primer sequence was $5^{\prime}$-CAGGAGACGGAGCCACAGAT-3' with an expected amplicon size of 59. For porcine $18 \mathrm{~S}$, the forward primer sequence was $5^{\prime}$-CCGCGGTTCTATTTTGTTGGTTTT- $3^{\prime}$, and the reverse primer sequence was $5^{\prime}$-CGGGCCGGGTGAGGTTTC- $3^{\prime}$ with an expected amplicon size of 399. To ensure specific amplification, controls including water only, no primers, and no template were included in the assay. Primer quality was evaluated, and dissociation curves for each primer set were checked. Data were analyzed using the relative standard curve method for quantitation of gene expression as described by Applied Biosystems (ABI User Bulletin 2, 2001). Standard curves were generated for each gene using twofold dilutions of cDNA from porcine corpus luteum of pregnancy. Target gene expression was normalized to the expression of porcine $18 \mathrm{~S}$, and data from qPCR analysis were presented as relative mRNA units. 


\section{Statistical analyses}

All data were subjected to ANOVA using general linear model procedures available with SAS (SAS 2009-2010, Cary, NC, USA). For assay validation data, statistical models were tested for heterogeneity of regression and considered effects of dose of RLX. For relative proRLX protein expression in milk data, statistical models accounted for variation due to sow, and bestfit least-squares regression was identified. Preplanned contrasts were performed to identify discrete effects of day: (a) LD 4 vs LD $7+$ LD 14; and (b) LD 7 versus LD 14. For mammary tissue protein and gene expression data, statistical models accounted for variation due to day. Error terms were identified based upon the expectations of the mean squares for error, and data were expressed as least-squares means with S.E.M.

\section{Declaration of interest}

The authors declare that there is no conflict of interest that could be perceived as prejudicing the impartiality of the research reported.

\section{Funding}

This work was supported by USDA-NRI-2003-35203-13572 and 2007-35203-18098 (to F F Bartol and C A Bagnell) and NSF EPS-0814103 (to F F Bartol).

\section{Acknowledgements}

The authors thank Laura Comerford, Karin Mezey, Brian Anderson, Dori Miller, and the staffs of the Rutgers University and Auburn University Animal Care Programs for their assistance in these studies.

\section{References}

Bagnell CA, McMurtry JP, Baker NK, Timtim JK \& Bryant-Greenwood GD 1987 Detection of relaxin by immunohistochemistry in the corpus luteum during lactation. Biology of Reproduction 37 1317-1325. (doi:10.1095/biolreprod37.5.1317)

Bagnell CA, Tashima L, Tsark W, Ali SM \& McMurtry JP 1990 Relaxin gene expression in the sow corpus luteum during the cycle, pregnancy, and lactation. Endocrinology 126 2514-2520. (doi:10.1210/endo-126-52514)

Bagnell CA, Steinetz BG \& Bartol FF 2009 Milk-borne relaxin and the lactocrine hypothesis for maternal programming of neonatal tissues. Annals of the New York Academy of Sciences 1160 152-157. (doi:10. 1111/j.1749-6632.2009.03834.x)

Bartol FF, Wiley AA \& Bagnell CA 2008 Epigenetic programming of porcine endometrial function and the lactocrine hypothesis. Reproduction in Domestic Animals 43 (Supplement 2) 273-279. (doi:10.1111/j.14390531.2008.01174.x)

Bathgate RA, Ivell R, Sanborn BM, Sherwood OD \& Summers RJ 2006 International Union of Pharmacology LVII: recommendations for the nomenclature of receptors for relaxin family peptides. Pharmacological Reviews 58 7-31. (doi:10.1124/pr.58.1.9)

Bryant-Greenwood GD, Jeffrey R, Ralph MM \& Seamark RF 1980 Relaxin production by the porcine ovarian graafian follicle in vitro. Biology of Reproduction 23 792-800. (doi:10.1095/biolreprod23.4.792)
Bullesbach EE \& Schwabe C 2000 The relaxin receptor-binding site geometry suggests a novel gripping mode of interaction. Journal of Biological Chemistry 275 35276-35280. (doi:10.1074/jbc.M005728200)

Chen JC, Wiley AA, Ho TY, Frankshun AL, Hord KM, Bartol FF \& Bagnell CA 2010 Transient estrogen exposure from birth affects uterine expression of developmental markers in neonatal gilts with lasting consequences in pregnant adults. Reproduction 139 623-630. (doi:10.1530/REP-09-0454)

Coalson JA \& Lecce JG 1973 Influence of nursing intervals on changes in serum proteins (immunoglobulins) in neonatal pigs. Journal of Animal Science 36 381-385.

Eddie LW, Sutton B, Fitzgerald S, Bell RJ, Johnston PD \& Tregear GW 1989 Relaxin in paired samples of serum and milk from women after term and preterm delivery. American Journal of Obstetrics and Gynecology 161 970-973.

Eldridge RK \& Fields PA 1985 Rabbit placental relaxin: purification and immunohistochemical localization. Endocrinology 117 2512-2519. (doi:10.1210/endo-117-6-2512)

Fei DTW, Gross MC, Lofgren JL, Mora-Worms M \& Chen AB 1990 Cyclic AMP response to recombinant human relaxin by cultured human endometrial cells - a specific and high throughput in vitro bioassay. Biochemical and Biophysical Research Communications 170 214-222. (doi:10.1016/0006-291X(90)91262-Q)

Fevold HL, Hisaw FL \& Meyer RK 1930 The relaxative hormone of the corpus luteum. Its purification and concentration. Journal of the American Chemical Society 52 3340-3348. (doi:10.1021/ja01371a051)

Frankshun AL, Ho TY, Steinetz BG, Bartol FF \& Bagnell CA 2009 Biological activity of relaxin in porcine milk. Annals of the New York Academy of Sciences 1160 164-168. (doi:10.1111/j.1749-6632.2008.03822.x)

Gast M 1982 Studies of luteal generation and processing of the high molecular weight relaxin precursor. Annals of the New York Academy of Sciences 380 111-125. (doi:10.1111/j.1749-6632.1982.tb18034.x)

Gast M 1983 Characterization of preprorelaxin by tryptic digestion and inhibition of its conversion to prorelaxin by amino acid analogs. Journal of Biological Chemistry 258 9001-9004.

Goldsmith LT, Lust G \& Steinetz BG 1994 Transmission of relaxin from lactating bitches to their offspring via suckling. Biology of Reproduction 50 258-265. (doi:10.1095/biolreprod50.2.258)

Gunnersen JM, Crawford RJ \& Tregear GW 1995 Expression of the relaxin gene in rat tissues. Molecular and Cellular Endocrinology 110 55-64. (doi:10.1016/0303-7207(95)03516-A)

Haley J, Hudson P, Scanlon D, John M, Cronk M, Shine J, Tregear G \& Niall H 1982 Porcine relaxin: molecular cloning and CDNA structure. DNA 1 155-162. (doi:10.1089/dna.1.1982.1.155)

Hausman GJ, Poulos SP, Richardson RL, Barb CR, Andacht T, Kirk HC \& Mynatt RL 2006 Secreted proteins and genes in fetal and neonatal pig adipose tissue and stromal-vascular cells. Journal of Animal Science $\mathbf{8 4}$ 1666-1681. (doi:10.2527/jas.2005-539)

Hsu SY, Nakabayashi K, Nishi S, Kumagai J, Kudo M, Sherwood OD \& Hsueh AJ 2002 Activation of orphan receptors by the hormone relaxin. Science 295 671-674. (doi:10.1126/science.1065654)

Kern A, Agoulnik Al \& Bryant-Greenwood GD 2007 The low-density lipoprotein class A module of the relaxin receptor (leucine-rich repeat containing G-protein coupled receptor 7): its role in signaling and trafficking to the cell membrane. Endocrinology 148 1181-1194. (doi:10.1210/en.2006-1086)

Ko JC, Williams BL, Smith VL, McGrath CJ \& Jacobson JD 1993 Comparison of telazol, telazol-ketamine, telazol-xylazine, and telazolketamine-xylazine as chemical restraint and anesthetic induction combination in swine. Laboratory Animal Science 43 476-480.

Krantz JC, Bryant HH \& Carr CJ 1950 The action of aqueous corpus luteum extract upon uterine activity. Surgery, Gynecology \& Obstetrics 90 372-375.

Kroc RL, Steinetz BG \& Beach VL 1959 The effects of estrogens, progestagens, and relaxin in pregnant and nonpregnant laboratory rodents. Annals of the New York Academy of Sciences 75 942-980. (doi:10.1111/j.1749-6632.1959.tb44603.x)

Layden SS \& Tregear GW 1996 Purification and characterization of porcine prorelaxin. Journal of Biochemical and Biophysical Methods 31 69-80. (doi:10.1016/0165-022X(95)00040-X) 
Lecce JG 1973 Effect of dietary regimen on cessation of uptake of macromolecules by piglet intestinal epithelium (closure) and transport to the blood. Journal of Nutrition 103 751-756.

Mazoujian G \& Bryant-Greenwood GD 1990 Relaxin in breast tissue. Lancet 335 298-299. (doi:10.1016/0140-6736(90)90124-N)

Meisel H 2005 Biochemical properties of peptides encrypted in bovine milk proteins. Current Medicinal Chemistry 12 1905-1919. (doi:10.2174/ 0929867054546618)

Neumann JL, Lazaris A, Huang YJ, Karatzas C, Ryan PL \& Bagnell CA 2006 Production and characterization of recombinant equine prorelaxin. Domestic Animal Endocrinology 31 173-185. (doi:10.1016/j.domaniend.2005.10.001)

O'Byrne EM \& Steinetz BG 1976 Radioimmunoassay (RIA) of relaxin in sera of various species using an antiserum to porcine relaxin. Proceedings of the Society for Experimental Biology and Medicine 152 272-276.

O'Byrne EM, Tabachnick M, Anderson LL \& Steinetz BG 1989 Characterization of the circulating form of porcine relaxin: biological activity and terminal amino acids. Endocrinology 124 2920-2927. (doi:10.1210/endo-124-6-2920)

Pardo R, Larkin LH \& Fields PA 1980 Immunocytochemical localization of relaxin in endometrial glands of the pregnant guinea pig. Endocrinology 107 2110-2112. (doi:10.1210/endo-107-6-2110)

Parsell DA, Mak JY, Amento EP \& Unemori EN 1996 Relaxin binds to and elicits a response from cells of the human monocytic cell line, THP-1. Journal of Biological Chemistry 271 27936-27941. (doi:10.1074/jbc. 271.44.27936)

Peaker M, Taylor E, Tashima L, Redman TL, Greenwood FC \& BryantGreenwood GD 1989 Relaxin detected by immunocytochemistry and northern analysis in the mammary gland of the guinea pig. Endocrinology 125 693-698. (doi:10.1210/endo-125-2-693)

Peavy DE, Abram JD, Frank BH \& Duckworth WC 1984 In vitro activity of biosynthetic human proinsulin. Receptor binding and biologic potency of proinsulin and insulin in isolated rat adipocytes. Diabetes 33 1062-1067. (doi:10.2337/diabetes.33.11.1062)

Sakbun V, Ali SM, Greenwood FC \& Bryant-Greenwood GD 1990 Human relaxin in the amnion, chorion, decidua parietalis, basal plate, and placental trophoblast by immunocytochemistry and northern analysis. Journal of Clinical Endocrinology and Metabolism 70 508-514. (doi:10. 1210/jcem-70-2-508)

Sherwood OD 1979 Purification and characterization of rat relaxin. Endocrinology 104 886-892. (doi:10.1210/endo-104-4-886)

Sherwood CD \& O'Byrne EM 1974 Purification and characterization of porcine relaxin. Archives of Biochemistry and Biophysics 160 185-196. (doi:10.1016/S0003-9861(74)80025-1)

Sherwood OD, Nara BS, Welk FA, First NL \& Rutherford JE 1981 Relaxin levels in the maternal plasma of pigs before, during, and after parturition and before, during, and after suckling. Biology of Reproduction 25 65-71. (doi:10.1095/biolreprod25.1.65)

Silvertown JD, Geddes BJ \& Summerlee AJ 2003 Adenovirus-mediated expression of human prorelaxin promotes the invasive potential of canine mammary cancer cells. Endocrinology 144 3683-3691. (doi:10. 1210/en.2003-0248)
Soloff MS, Shaw AR, Gentry LE, Marquardt H \& Vasilenko P 1992 Demonstration of relaxin precursors in pregnant rat ovaries with antisera against bacterially expressed rat prorelaxin. Endocrinology 130 1844-1851. (doi:10.1210/en.130.4.1844)

Steinetz BG, Williams AJ, Lust G, Schwabe C, Bullesbach EE \& Goldsmith LT 2008 Transmission of relaxin and estrogens to suckling canine pups via milk and possible association with hip joint laxity. American Journal of Veterinary Research 69 59-67. (doi:10.2460/ajvr. 69.1.59)

Steinetz BG, Horton L \& Lasano S 2009 The source and secretion of immunoactive relaxin in rat milk. Experimental Biology and Medicine 234 562-565. (doi:10.3181/0811-BC-341)

Stewart DR \& Papkoff H 1986 Purification and characterization of equine relaxin. Endocrinology 119 1093-1099. (doi:10.1210/endo-119-3-1093)

Tashima LS, Mazoujian G \& Bryant-Greenwood GD 1994 Human relaxins in normal, benign and neoplastic breast tissue. Journal of Molecular Endocrinology 12 351-364. (doi:10.1677/jme.0.0120351)

Van Cott KE, Williams B, Velander WH, Gwazdauskas F, Lee T, Lubon H \& Drohan WN 1996 Affinity purification of biologically active and inactive forms of recombinant human protein $\mathrm{C}$ produced in porcine mammary gland. Journal of Molecular Recognition 9 407-414. (doi:10.1002/ (SICI)1099-1352(199634/12)9:5/6 < 407::AID-JMR277> 3.0.CO;2-X)

Vu AL, Green CB, Roby KF, Soares MJ, Fei DT, Chen AB \& Kwok SC 1993 Recombinant porcine prorelaxin produced in Chinese hamster ovary cells is biologically active. Life Sciences 52 1055-1061. (doi:10.1016/ 0024-3205(93)90198-C)

Yan W, Wiley AA, Bartol FF \& Bagnell CA 2005 Tissue-specific effects of relaxin on the reproductive tract of neonatal gilts. Annals of the New York Academy of Sciences 1041 132-135. (doi:10.1196/annals.1282.019)

Yan W, Wiley AA, Bathgate RA, Frankshun AL, Lasano S, Crean BD, Steinetz BG, Bagnell CA \& Bartol FF 2006 Expression of LGR7 and LGR8 by neonatal porcine uterine tissues and transmission of milk-borne relaxin into the neonatal circulation by suckling. Endocrinology 147 4303-4310. (doi:10.1210/en.2006-0397)

Yan W, Chen J, Wiley AA, Crean-Harris BD, Bartol FF \& Bagnell CA 2008 Relaxin (RLX) and estrogen affect estrogen receptor alpha, vascular endothelial growth factor, and RLX receptor expression in the neonatal porcine uterus and cervix. Reproduction 135 705-712. (doi:10.1530/ REP-08-0014)

Zarreh-Hoshyari-Khah R, Bartsch O, Einspanier A, Pohnke Y \& Ivell R 2001 Bioactivity of recombinant prorelaxin from the marmoset monkey. Regulatory Peptides 97 139-146. (doi:10.1016/S0167-0115 (00)00205-6)

Received 20 September 2010

First decision 29 October 2010

Revised manuscript received 2 December 2010

Accepted 22 December 2010 